\title{
Micropropagation of Pacific Dogwood
}

\author{
John L. Edson ${ }^{1}$, David L. Wenny ${ }^{2}$, and Annette Leege-Brusven ${ }^{3}$ \\ The Micropropagation Unit, Forest Research Nursery, Department of Forest \\ Resources, University of Idaho, Moscow, ID 83843
}

Additional index words. Cornus nuttallii, shoot regeneration, root regeneration, benzyladenine

\begin{abstract}
Idaho's population of Pacific dogwood (Cornus nuttallii Audubon) has declined. Propagation of disease-resistant clones would be useful to horticulturists and conservation biologists. In vitro-derived microshoots, incubated for 1 month on woody plant medium supplemented with $6.04 \mathrm{~mm}$ calcium gluconate and $4.44 \mu_{\mathrm{M}}$ benzyladenine, produced an average of 3.1 axillary microshoots per explant. Up to $62 \%$ of the elongated microshoots had rooted ex vitro 5 weeks following a 4.5\% IBA talc dip. Plantlets resumed shoot growth within 2 months of acclimatization, and 70\% survived after 1 year. This protocol is more rapid and efficient than propagation by layering or rooting the difficult-to-root stem cuttings of this species. Chemical names used: $2,3,4,5,6$-pentahydroxy-caproic acid (calcium gluconate), benzyladenine (BA), 3-indolebutyric acid (IBA).
\end{abstract}

Pacific dogwood, also known as western flowering dogwood, is a small, showy tree native to the forests of the U.S. Pacific coast and one location in northern Idaho. Pacific dogwood cultivars (Santamour and McArdle, 1985) are primarily propagated by budding and grafting (Macdonald, 1984). However, dogwood anthracnose (Discula destructiva Redlin) (Redlin, 1991), a disease of North American flowering dogwoods, and a root rot caused by Phytopthora sp. may advance the decline of Idaho's Pacific dogwood population (Hibben, 1992; Partridge, 1990). If selections of symptom-free Pacific dogwood show genetic resistance to dogwood anthracnose, then a procedure to rapidly propagate the resistant clones would be useful to horticulturists and conservation biologists. Because there are no published reports on the micropropagation of Pacific dogwood to our knowledge, we describe methods for proliferating shoots in vitro and rooting microcuttings ex vitro.

\section{Materials and Methods}

Softwood branch tips (10 to $15 \mathrm{~cm}$ long) were collected from the following sources: 20 forest trees in the Puget Basin of western Washington; 20 trees in northern Idaho; and 75 greenhouse-grown, 2-year-old seedlings from the Idaho population. Defoliated shoot tips were washed under running tap water for $1 \mathrm{~h}$, agitated for $30 \mathrm{~min}$ in a 3-liter Erlenmeyer flask by bubbling air through an aqueous solu-

Received for publication 7 Mar. 1994. Accepted for publication 28 July 1994. Idaho Forest, Wildlife, and Range Expt. Station Contribution no. 724. This work was funded by the Mazamas of Portland, Ore., and a McIntire-Stennis grant. We gratefully acknowledge Sue Morrison for technical assistance and Robert Tripepi for reviewing this paper. The cost of publishing this paper was defrayed in part by the payment of page charges. Under postal regulations, this paper therefore must be hereby marked advertisement solely to indicate this fact.

${ }^{1}$ Research Associate.

${ }^{2}$ Professor.

${ }^{3}$ Micropropagation Specialist. tion of two drops detergent/liter (Liquinox, New York), and surface-sterilized in a continuously stirred $1.5 \%(\mathrm{w} / \mathrm{v}) \mathrm{NaOCl}$ solution for $15 \mathrm{~min}$. After four rinses in sterile distilled water, each shoot was sectioned into a tip and several stem segments that contained a single node. The cultures were initiated on hormonefree Murashige and Skoog (MS) medium (Murashige and Skoog, 1962), supplemented with $3 \%$ sucrose and $0.7 \%$ agar (Sigma Chemical Co., St. Louis) at pH 5.7. Contamination percentages were compared for forest and greenhouse sources. Cultures contaminated with bacteria underwent up to four, shortinterval ( 1 to 2 weeks) subcultures to reduce bacterial growth.

All experiments used microshoots derived from one to four subcultures of the previous shoot tip and stem segment explants. Microshoots were incubated individually for 1 month in $25 \times 150$-mm glass test tubes, loosely covered with cotton-filled caps (Magenta Co., Chicago). Cultures were placed on shelves under an 18-h photoperiod provided by coolwhite fluorescent lights $(40 \mathrm{~W})$ that produced $20 \mu \mathrm{mol} \cdot \mathrm{m}^{-2} \cdot \mathrm{s}^{-1}$ photosynthetically active radiation at the leaf surface of the cultures. Diurnal temperatures in the laboratory ranged from $27 / 22 \mathrm{C}$ (day/night).

To assess the effect of BA on multiplication, 120 in vitro-derived microshoots from the forest sources were assigned to the MS ( $0.8 \%$ agar) medium supplemented with 0.0 , $0.44,2.22$, or $4.44 \mu \mathrm{M}$ BA in a completely randomized design. To compare the influence of basal media on shoot elongation and proliferation, 116 in vitro-derived, $0.5-\mathrm{cm}$-long microshoots (forest sources) were assigned to two replicates of MS and woody plant medium (WPM) (Lloyd and McCown, 1980) in a randomized complete-block design (RCB). WPM contained $2 \%$ sucrose and $0.6 \%$ agar and was adjusted to pH 5.2. Both media (MS and WPM) contained $4.44 \mu \mathrm{M}$ BA and $6.04 \mathrm{~mm}$ calcium gluconate. To determine proliferation on WPM supplemented with combinations of BA and $\alpha$-naphthaleneacetic acid (NAA), $150 \mathrm{mi}-$ croshoots (greenhouse source) were assigned to two replications of three treatments on WPM: a control (0 BA and NAA), $4.44 \mu \mathrm{M} \mathrm{BA}$, and $4.44 \mu_{\mathrm{M}} \mathrm{BA}$ in combination with $0.54 \mu_{\mathrm{M}}$ NAA in an RCB design. Data were collected 1 month after initiating experiments. To establish multiplication over time, 10 in vitro-derived microshoots (greenhouse source) were multiplied and subcultured monthly on WPM with $4.44 \mu \mathrm{M}$ BA for five consecutive months. Shoot counts and height increments were processed by analysis of variance, and the treatment means were separated by Tukey's HSD multiple comparison procedure at $\alpha=0.05$. Maximum-likelihood analysis of variance and treatment contrasts using SAS category modeling procedure (SAS Institute, 1989) were performed on health scores $(0=$ dead, $1=$ necrotic, 2 = chlorotic, 3 = vigorous). Hand sections of new shoots were examined microscopically to evaluate axillary or adventitious origin.

To evaluate ex vitro rooting, 160 in vitroderived, 1.5 - to $3.0-\mathrm{cm}$-long microshoots (greenhouse source) were assigned to two replicates of talc dips with $0 \%, 0.1 \%, 0.8 \%$, $1.6 \%$, or $4.5 \%$ IBA. The bases of the treated microshoots were inserted in $6-\mathrm{cm}^{3}$ plug containers filled with a 2 perlite : 1 peat : 1 vermiculite mix (by volume). The microshoots were placed in fog ( $88 \%$ to $92 \%$ relative humidity), at 20 to $25 \mathrm{C}$, under $70 \%$ shade, and with light intensities $\leq 12,000 \mathrm{~lx}$ and natural photoperiod. Twenty plantlets were fertilized weekly for 12 weeks with $20 \mathrm{~N}-20 \mathrm{P}-20 \mathrm{~K}$ at $150 \mathrm{ppm} N$ (16-h photoperiod) in the greenhouse.

\section{Results and Discussion}

Fewer explants from the greenhouse seedlings were contaminated with fungus than from the forest trees (18\% vs. $75 \%)$. Trigiano et al. (1992) reported high contamination rates with explants from forest trees of $C$. florida $\mathrm{L}$. All explants from the forest sources and $\approx 25 \%$ from the greenhouse source developed slowgrowing bacteria that generally disappeared after two to four subcultures. The average number of new shoots per explant (forest source) on the MS medium supplemented with BA at $4.44 \mu_{\mathrm{M}}$ was higher than on hormonefree MS $(P \leq 0.0010)$. The shoot counts were (mean $\pm \mathrm{SD}$ ) $0.6 \pm 0.5,1.8 \pm 1.2,2.3 \pm 1.0$, and $3.3 \pm 1.6$ for $0,0.44,2.22$, and $4.44 \mu \mathrm{M} \mathrm{BA}$, respectively. Comparing microshoot response on WPM vs. MS, the new shoots produced per explant were more numerous $(2.6 \mathrm{vs} .0 .7)(P=$ $0.0003)$, taller $(1.2$ vs. $0.9 \mathrm{~cm})(P=0.0001)$, and less chlorotic (health score 2.7 vs. 2.1$)(P$ $=0.0002)$ on WPM. Bacterial growth during this experiment may have depressed proliferation to 0.7 shoots per explant vs. 3.3 in the previous experiment (both results on MS with $4.44 \mu \mathrm{M}$ BA). Shoot proliferation was slightly higher in the microshoots (greenhouse source) incubated on WPM supplemented with 4.44 $\mu \mathrm{M}$ BA alone vs. $4.44 \mu \mathrm{M}$ BA combined with $0.54 \mu \mathrm{M}$ NAA $(P=0.0051)$ (Table 1$)$. Moreover, the explants on growth regulators were less chlorotic than on hormone-free WPM $(P$ $=0.0006)$. Multiplication over the five monthly 
subcultures resulted in an average of 2.9 shoot tips produced per culture per month. Pacific dogwood on WPM supplemented with 4.44 $\mu \mathrm{M}$ BA proliferated at rates similar to those reported by Trigiano et al. (1992) for C. florida on Knop's medium. New microshoots produced an opposite or whorled habit typical of Pacific dogwood's axillary growth, and vascular traces examined were continuous with the main stem.

In contrast to recalcitrant rooting of $C$. florida (Trigiano et al., 1992), Pacific dogwood microshoots rooted ex vitro after 5 weeks, with final rooting rates of $62 \%$ and $43 \%$ in the two replicates treated with $4.5 \%$ IBA. Microshoots receiving $0 \%$ or $0.1 \%$ IBA failed to root, and only $18 \%$ of the microshoots treated

with $0.8 \%$ or $1.6 \%$ IBA rooted. Plantlets resumed shoot growth within 2 months of transfer to the acclimatization greenhouse and survived at $70 \%$ after 1 year.

Pacific dogwood can be micropropagated by 1) using greenhouse stock plants to minimize contamination and enhance in vitro growth, 2) multiplying microshoots on WPM containing $4.44 \mu \mathrm{MBA}, 3$ ) rooting microshoots ex vitro using a $4.5 \%$ IBA talc dip, and 4) acclimatizing in a greenhouse. This propagation protocol is more rapid and efficient than layering or rooting the difficult-to-root stem cuttings of this species. Furthermore, rooting microshoots ex vitro lowers overall propagation costs and enhances the feasibility of commercial production.

Table 1. Effects of BA and NAA combinations on multiplication of Pacific dogwood microshoots derived from greenhouse seedlings. ${ }^{\mathrm{z}}$

\begin{tabular}{|c|c|c|c|c|}
\hline \multirow{2}{*}{\multicolumn{2}{|c|}{$\begin{array}{c}\text { Growth regulator } \\
\text { treatment }(\mu \mathrm{M})\end{array}$}} & \multicolumn{3}{|c|}{ Shoots } \\
\hline & & \multirow{2}{*}{$\begin{array}{c}\text { Mean } \\
\text { no. }\end{array}$} & \multirow{2}{*}{$\begin{array}{c}\text { Mean } \\
\text { elongation }(\mathrm{mm})^{\mathrm{y}}\end{array}$} & \multirow{2}{*}{$\begin{array}{c}\text { Mean } \\
\text { health score }\end{array}$} \\
\hline$\overline{\mathrm{BA}}$ & $\overline{\text { NAA }}$ & & & \\
\hline$\overline{0}$ & 0 & $0.2 \mathrm{a}$ & $2 a$ & $1.8 \mathrm{a}$ \\
\hline 4.44 & 0 & $3.1 \mathrm{~b}$ & $6 \mathrm{~b}$ & $2.4 \mathrm{~b}$ \\
\hline 4.44 & 0.54 & $2.2 \mathrm{c}$ & $8 c$ & $2.3 \mathrm{~b}$ \\
\hline
\end{tabular}

${ }^{2}$ Fifty explants were used per treatment.

yeans separation in columns by Tukey's HSD at $\alpha=0.05$.

${ }^{x}$ Shoot health rated on a scale from 0 to $3(0=$ dead, $1=$ necrosis, $2=$ chlorosis, and $3=$ vigorous growth $)$.

Treatment mean separation determined by contrasts of maximum likelihood estimates.

\section{Literature Cited}

Hibben, C.R. 1992. Anthracnose in a coastal disjunct population of Pacific dogwood in Idaho: An evaluation based on comparisons with the disease in Eastern flowering dogwood. U.S. Dept. Agr. For. Serv. Rpt., Missoula, Mont.

Lloyd, G. and B. McCown. 1980. Commerciallyfeasible micropropagation of mountain laurel, Kalmia latifolia, by use of shoot-tip culture. Proc. Intl. Plant Prop. Soc. 30:421-427.

Macdonald, B. 1984. Two noteworthy Cornus introductions. J. Royal Hort. S. 109:151-153.

Murashige, T. and F. Skoog. 1962. A revised medium for rapid growth and bioassays with tobacco tissue cultures. Physiol. Plant. 15:473497.

Partridge, A.D. 1990. Mortality of Pacific dogwood, a coastal disjunct population in northern Idaho. U.S. Dept. Agr. For. Serv. Rpt., Missoula, Mont.

Redlin, S.C. 1991. Discula destructiva sp. nov., cause of dogwood anthracnose. Mycologia 83:633-642.

Santamour, F.S. and A.J. McArdle. 1985. Cultivar checklists of the large-bracted dogwoods: Cornus florida, C. kousa, and C. nuttallii. J. Arboriculture 11:29-36.

SAS Institute. 1989. SAS/STAT user's guide. Version 6, 4th ed. vol. 1. SAS Inst., Cary, N.C.

Trigiano, R.N., R.M. Beaty, and K.W. Lowe. 1992. Micropropagation of dogwoods (Cornus spp.), p. 81-90. In: Y.P.S. Bajaj (ed.). Biotechnology in agriculture and forestry. vol. 20. SpringerVerlag, Berlin. 